\title{
Roles of Contractors in Process Safety
}

\author{
Nafiz Tamim ${ }^{1}$, Susie Scott ${ }^{2}$, Wen Zhu ${ }^{1}$, Yogesh Koirala ${ }^{1}$ and M. Sam Mannan ${ }^{1}$ \\ ${ }^{1}$ Mary Kay O’Connor Process Safety Center, Artie McFerrin Department of Chemical Engineering, Texas A\&M University, \\ College Station, Texas 77843-3122, USA
}

${ }^{2}$ Oliver Wyman, 500 Dallas Street, Suite 1500, Houston, TX 77002

\begin{abstract}
Process safety starts at the conceptual phase and continues throughout the entire life cycle of an asset. From process selection to de-commissioning, various process safety elements govern the safety and reliability of the total system. Contractors play a crucial role in project execution including detailed design, technology selection, plant layout, commissioning, start-up, and further expansion, modification and maintenance activities. The interface/interaction of the contractor with the operator/owner often defines the importance of process safety throughout this life cycle. Undoubtedly, these are the most critical phases of a plant life cycle which could trigger an unexpected or uncontrolled situation leading to a catastrophic incident. This paper discusses the impact of the contractors' role during major process safety events including the Phillips explosion in Pasadena (1989), Sonat vessel failure (1998), Texas City Refinery explosion (2005), T2 Laboratories explosion (2007) and a few others. Lessons from past incidents are highlighted and an in-depth analysis is conducted to identify essential process safety components for different groups of contractors and for the different phases of projects. Different aspects of process safety functional elements are presented and discussed for both greenfield and brownfield projects. A Comprehensive understanding of process safety and risk management is required by all levels of contractors to ensure risk-based decision making and hazard mitigation. Besides the process safety expertise needed by the contractors, the necessity of having a consistent and harmonized interaction between the operators/owners and the contractors is also emphasized.
\end{abstract}

Keywords: Contractor Management, Process Safety Competency, Project Management, Project Life Cycle, Design Safety

\section{INTRODUCTION}

Contractors are an integral part of the modern industrial era due to their role in plant/platform design, construction, commissioning and maintenance. They play a very crucial role in managing

*Corresponding Author: M. Sam Mannan, Phone: +1 979862 3985, E-mail: mannan@tamu.edu 
risk throughout the plant life cycle and the engineering and design phases are undoubtedly the most crucial stages for incorporating process safety concepts. The choices made during the design phase impact everything in the future from operations to modifications and finally decommissioning. A single flaw during the design phase, could be carried throughout the plant life cycle and with some unfavorable conditions, may eventually cause a catastrophic incident.

In the first section, statistical analyses and incident case studies are presented to demonstrate the involvement of the contractors. The investigation clearly shows the need to engage the contractors to build awareness in both process and personnel safety. In the following section, a life cycle based approach is discussed where different process safety functional elements are identified for specific design tasks and phases. So far, separate responsibilities have been identified and discussed for the owners and the contractors. However, for best results, both parties need to work together to build a healthy interface with common expectations and understanding in terms of achieving safety goals. The owners and the contractors share some common responsibilities for establishing a harmonized approach to ensure process safety standards. Creating a common baseline of understanding in process safety is the prerequisite for achieving that goal. The third and final section of this article provides a discussion on existing practices and current initiatives to build process safety competency programs for contractors especially for the design engineers. Six learning modules have been identified with appropriate process safety functional elements to allow effective integration of process safety during the engineering and design phases.

\section{STATISTICAL ANALYSIS AND INCIDENT CASE STUDIES}

\section{Statistical Analysis of Incidents}

From 2011 to 2014, a total of 2,808 contractors were killed at work in the US accounting for $15 \%$ of the total fatal occupational injuries. The U.S. Occupational Safety and Health Administration (OSHA) observed that fatal work injuries involving contractors accounted for $17 \%$ of all fatal work injuries in 2014 [1]. Starting from 2011, the U.S. Census of Fatal Occupational Injuries (CFOI) began capturing both the fatalities in the firm that are directly employing and the firm that contracted. CFOI is a sub-branch of the Bureau of Labor Statistics (BLS) ${ }^{\mathrm{i}}$. According to the data published by CFOI, Figure 1 shows the number and percentage ${ }^{\mathrm{ii}}$ of fatalities of contractors versus employees.

The percentage of the contractor fatality increased from $12 \%$ to $17 \%$ from 2011 to 2014 . Also, if we closely look at the data for chemical manufacturing, the percentage of fatal occupational injuries grows to $22 \%$ for the contractors (Figure 2) and for petroleum refineries, the percentage is as high as $67 \%$ (Figure 3). Even though the data provided in Figures 2 and 3 do not represent the complete statistical data set, they do indicate that the chemical process industries need to take more

\footnotetext{
${ }^{i}$ The Bureau of Labor Statistics (BLS) is a unit of United States Department of Labor and it serves as a principal agency for the U.S. Federal Statistical system.

ii Data Sources: Retrieved from BLS-Injuries, Illnesses, and Fatalities, http://www.bls.gov/iif/oshcfoi1.htm Miscellaneous CFOI data table- All worker profile, 2003-2014

Miscellaneous CFOI data table- Fatal occupational injuries incurred by contracted workers, 2011-2014
} 
measures in terms of establishing process safety practices and standards to protect both contractors and employees.



Figure 1. Comparison of fatality numbers/percentage for contractors and other employees (2011-2014)

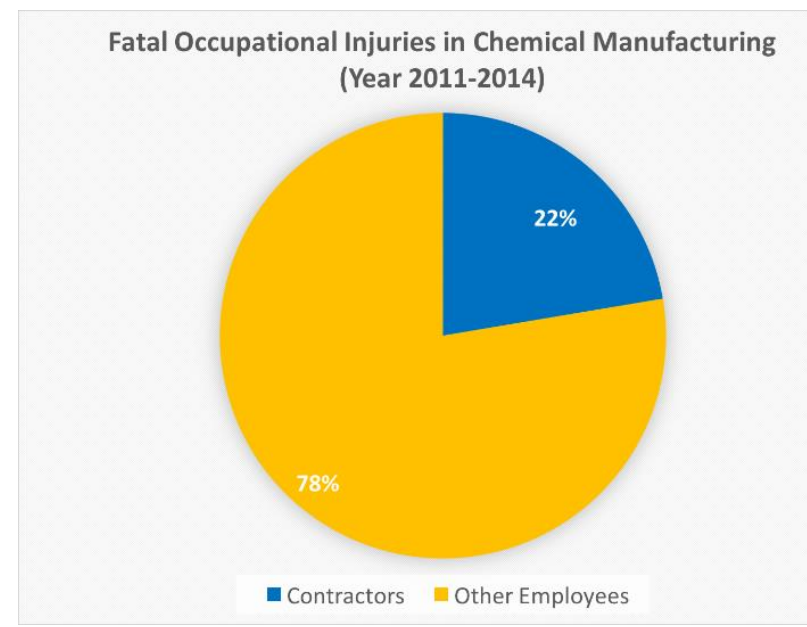

Figure 2. Comparison of fatalities of the contractors and other employees from 2011 to 2014 in the Chemical Manufacturing Industry.
Fatal Occupational Injuries in Petroleum Refineries (Year 2011-2014)



Figure 3. Comparison of fatalities of the contractors and other employees from 2011 to 2014 in the Petroleum Refineries.

\section{Major Incidents}

Over the past few decades, the energy and chemical industries have witnessed a significant number of catastrophic incidents, many of which involved contractors. Basic understanding of process safety issues could have prevented the incidents or minimized the consequences. Some of the 
major incidents involving contractors in different phases of the plants' life cycle are listed and discussed in Table 1. 
$\underline{\text { Table 1: List of Major Incidents }}$

\begin{tabular}{|c|c|c|}
\hline Incident & Brief Description & Incident Root Causes \\
\hline $\begin{array}{l}\text { Phillips } \\
\text { Explosion in } \\
\text { Pasadena } \\
\text { October 23, } \\
1989\end{array}$ & $\begin{array}{l}\text { Flammable process gases released and exploded } \\
\text { during regular maintenance operations on one of } \\
\text { the plant's polyethylene reactors. The incident } \\
\text { caused } 24 \text { deaths ( } 20 \text { Phillips employees and } 4 \\
\text { contractors) and } 132 \text { injuries [2] } \\
\text { 1. Air hoses were connected backwards which } \\
\text { automatically opened the valve } \\
\text { 2. The lockout device that prevented someone } \\
\text { from opening a valve was removed }\end{array}$ & $\begin{array}{l}\text { - Lack of process hazard analysis } \\
\text { - Lack of human factors } \\
\text { consideration in design } \\
\text { - Inadequate operating and } \\
\text { isolation procedures } \\
\text { - Lack of combustible gas } \\
\text { detection system } \\
\text { - Inadequate ventilation systems } \\
\text { and pressure relief system } \\
\text { - Inappropriate facility siting } \\
\text { - Failure to learn from past } \\
\text { incidents }\end{array}$ \\
\hline $\begin{array}{l}\text { ARCO } \\
\text { Channelview } \\
\text { Explosion } \\
\text { July 5, } 1990\end{array}$ & $\begin{array}{l}\text { Wastewater tank exploded during restart of a } \\
\text { compressor. The nitrogen purge was reduced } \\
\text { significantly during maintenance and a } \\
\text { temporary oxygen analyzer failed to detect } \\
\text { oxygen buildup as it was in a dead zone. } \\
\text { The explosion killed } 17 \text { people (5 employees } \\
\text { and } 12 \text { contractors) and caused } 5 \text { injuries [3] [4] }\end{array}$ & $\begin{array}{l}\text { - Inadequate hazard analysis and } \\
\text { safety measures during non- } \\
\text { routine operations } \\
\text { - Lack of comprehensive MOC } \\
\text { process } \\
\text { - Lack of competency and } \\
\text { knowledge on flammability }\end{array}$ \\
\hline $\begin{array}{l}\text { Sonat } \\
\text { Exploration } \\
\text { Co. } \\
\text { Catastrophic } \\
\text { Vessel Failure } \\
\text { March 4, } 1998\end{array}$ & $\begin{array}{l}\text { During purging operations, a separation vessel } \\
\text { failed catastrophically, releasing flammable gas } \\
\text { which ignited and caused } 4 \text { fatalities (including } \\
3 \text { contractors). } \\
\text { 1. Absence of an inlet valve caused high } \\
\text { pressure flammable gas to enter from adjacent } \\
\text { bypass line } \\
\text { 2. Two outlet block valves were closed and the } \\
\text { high pressure gas could not released } \\
\text { 3. The separator was designed as an } \\
\text { atmospheric vessel with no overpressure } \\
\text { protection [5] [6] }\end{array}$ & $\begin{array}{l}\text { - Lack of a formal engineering } \\
\text { design review process } \\
\text { - Improper hazard analysis during } \\
\text { design and construction phase } \\
\text { - Lack of adequate pressure relief } \\
\text { systems } \\
\text { - No operating procedures for non- } \\
\text { routine operations (start-up) }\end{array}$ \\
\hline $\begin{array}{l}\text { Formosa } \\
\text { Plastics } \\
\text { Explosion } \\
\text { April 23, 2004 }\end{array}$ & $\begin{array}{l}\text { Large quantity of highly flammable vinyl } \\
\text { chloride monomer was released from a reactor } \\
\text { and exploded causing } 5 \text { fatalities and } 2 \text { injuries } \\
\text { [7]. } \\
\text { 1. The reactor groupings had similar lay-out and } \\
\text { was susceptible to human error. } \\
\text { 2. The manual interlock bypass made provisions } \\
\text { for unauthorized usage }\end{array}$ & $\begin{array}{l}\text { - Lack of Human Factors } \\
\text { consideration in design } \\
\text { - Lack of safer facility layout } \\
\text { consideration } \\
\text { - Failure to learn from past } \\
\text { incidents }\end{array}$ \\
\hline
\end{tabular}




\begin{tabular}{|c|c|c|}
\hline Incident & Brief Description & Incident Root Causes \\
\hline $\begin{array}{l}\text { Texas City } \\
\text { Refinery } \\
\text { Explosion } \\
\text { March 23, } \\
2005\end{array}$ & $\begin{array}{l}\text { A hydrocarbon vapor cloud explosion occurred } \\
\text { at the isomerization process unit which was } \\
\text { being restarted after a maintenance turnaround. } \\
\text { The blast killed } 15 \text { contractors and injured more } \\
\text { than } 170 \text { others. }\end{array}$ & $\begin{array}{l}\text { - Inappropriate design and } \\
\text { maintenance } \\
\text { - Inadequate hazard analysis and } \\
\text { safety measures during non- } \\
\text { routine operations } \\
\text { - Failure to develop and } \\
\text { implement corrective actions } \\
\text { resulting from previous incident } \\
\text { - Inappropriate placement of } \\
\text { portable trailers }\end{array}$ \\
\hline $\begin{array}{l}\text { Thunder } \\
\text { Horse PDQ } \\
\text { Tilting } \\
\text { July 11, } 2005\end{array}$ & $\begin{array}{l}\text { The semi-submersible oil platform in the Gulf } \\
\text { of Mexico was found with a } 20^{\circ}-30^{\circ} \text { list after } \\
\text { the passage of hurricane Dennis [17]. It was } \\
\text { primarily caused due to uncontrolled flow of } \\
\text { water between several ballast tanks. A } \\
\text { combination of wrong positioning of valves and } \\
\text { incorrect operational actions caused the event. }\end{array}$ & $\begin{array}{l}\text { - Inappropriate engineering design } \\
\text { of ballast valve systems } \\
\text { - Lack of adequate risk assessment } \\
\text { during replacement } \\
\text { - Failure to learn from past } \\
\text { incidents } \\
\text { - Lack of quality control }\end{array}$ \\
\hline $\begin{array}{l}\text { T2 } \\
\text { Laboratories } \\
\text { Explosion in } \\
\text { Jacksonville, } \\
\text { Florida } \\
\text { December 19, } \\
2007\end{array}$ & $\begin{array}{l}\text { The explosion happened during the production } \\
\text { of a gasoline additive, where cooling system } \\
\text { failure resulted in a runaway chemical reaction } \\
\text { [8] causing } 4 \text { fatalities and } 32 \text { injuries. } \\
\text { 1. The cooling system was susceptible to single- } \\
\text { point failure due to a lack of design redundancy. } \\
\text { 2. The relief system was incapable of relieving } \\
\text { increased pressure }\end{array}$ & $\begin{array}{l}\text { - Failed to recognize the runaway } \\
\text { reaction hazard } \\
\text { - Inadequate hazard analysis and } \\
\text { ALARP } \\
\text { - Inadequate design of the cooling } \\
\text { and relief systems }\end{array}$ \\
\hline $\begin{array}{l}\text { Deepwater } \\
\text { Horizon } \\
\text { Blowout } \\
\text { April 20, } 2010\end{array}$ & $\begin{array}{l}\text { A well control event led to massive hydrocarbon } \\
\text { leak and resulted in large explosions and fire on } \\
\text { the Deepwater Horizon rig. The incident caused } \\
11 \text { fatalities and } 17 \text { injuries. Failure in several } \\
\text { areas caused the catastrophe [9]: } \\
\text { 1. Cement failure } \\
\text { 2. Inadequate negative pressure test and result } \\
\text { interpretation } \\
\text { 3. Well control action failure } \\
\text { 4. BOP failure }\end{array}$ & $\begin{array}{l}\text { - Lack of risk assessment after } \\
\text { changes in well design and } \\
\text { procedures } \\
\text { - Poor decision-making } \\
\text { - Inadequate communication } \\
\text { within and between operators } \\
\text { and its contractors } \\
\text { - Lack of training and supervision } \\
\text { on critical operations }\end{array}$ \\
\hline $\begin{array}{l}\text { Fire Ink Dust } \\
\text { Explosion and } \\
\text { Flash Fires in } \\
\text { East } \\
\text { Rutherford, } \\
\text { New Jersey } \\
\text { October } 9 \text {, } \\
2012\end{array}$ & $\begin{array}{l}\text { A large flash fire and explosion which caused } 7 \\
\text { burn injuries [10] occurred due to: } \\
\text { 1. Accumulation of combustible dust inside a } \\
\text { poorly designed dust collection system } \\
\text { 2. Dust collection system not designed to } \\
\text { prevent and control fires } \\
\text { 3. System controls, such as temperature and } \\
\text { pressure transmitters, were not installed to } \\
\text { monitor the mixing tanks and dust collection } \\
\text { system. }\end{array}$ & $\begin{array}{l}\text { - Lack of comprehensive MOC } \\
\text { program } \\
\text { - Inadequate contractor oversight } \\
\text { during the project } \\
\text { - Lack of risk and hazard } \\
\text { assessments before start-up of } \\
\text { the new dust collection system } \\
\text { - Failure to develop and } \\
\text { implement corrective actions } \\
\text { resulting from previous incident }\end{array}$ \\
\hline
\end{tabular}




\section{Case Study: Sonat Explosion}

To demonstrate the importance of having a sound knowledge of process safety for designing a plant/process, we analyzed the catastrophic vessel failure incident mentioned in Table 1. That incident happened on March 4, 1998, near Pitkin, Louisiana, at the Temple 22-1 common point separation facility owned by Sonat Exploration Company. A separation vessel failed catastrophically due to overpressurization which resulted in a fire and killed four people including three contractors. As per the U.S. Chemical Safety Board (CSB) investigation findings [5], the facility was constructed without detailed engineering design reviews and hazard analyses. As a result, the risk of vessel overpressurization was ignored and the vessel wasn't equipped with adequate pressure-relief devices.



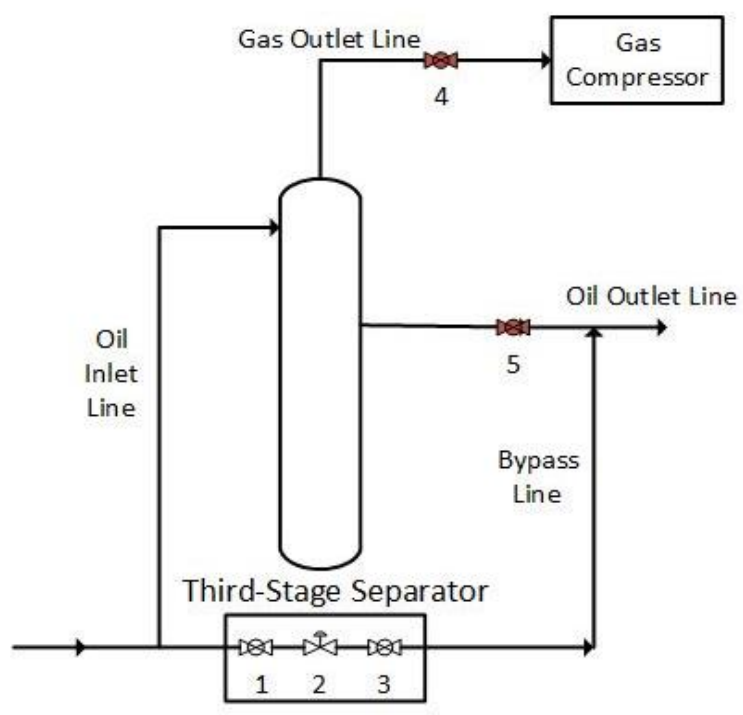

Planned Condition

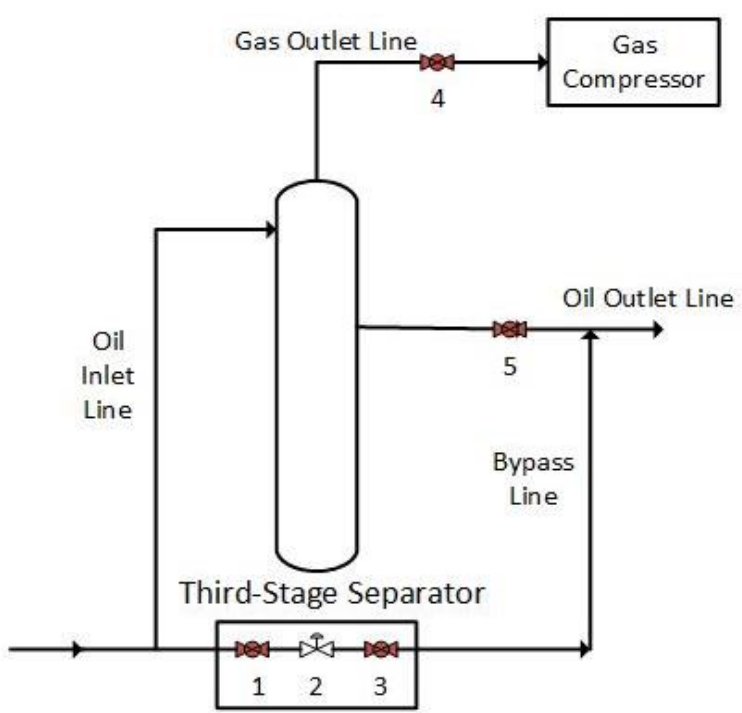

Reality

Figure 4. Comparison of valve alignments as planned and as found after the incident

The facility was designed to receive high-pressure three-phase (crude oil, natural gas, and water) stream from the wells. In that facility, there were two separation trains (one test train and another larger bulk train). Each train was comprised of three separators connected in series. On the day of the incident, Sonat planned to initiate production using the newly constructed bulk train. Before start-up, the bulk train and connected pipelines had to be purged to remove the air by using the fluid from the wells. Purging is a common practice that helps to decrease the risk of fire by removing air. The original plan was to purge the pipelines first then the bulk train. However, the order was reversed due to some issues with the well. One hour after purging started, the third-stage separator vessel failed and the flammable gas was released and ignited. The fire damaged the 
nearby pipelines. Additional flammable gas was released and ignited which killed four people instantly.

Following an incident investigation, the U.S. Chemical Safety Board (CSB) discovered [5] that there was no inlet valve to help isolate the separator vessel from the high-pressure fluid ( $800 \mathrm{psig}$ ). Also at that time, valves numbered 1 and 3 (figure 2) were closed which affected the venting process. The separator was originally designed to be used as an atmospheric vessel without venting valves or any sort of pressure relief system. As a result, the vessel got exposed to high pressure stream and failed due to overpressurization.

This incident reflects the vital importance of having process safety competency during engineering design. The engineers who were involved in the design phase did not perform necessary hazard and consequence analysis for the third-stage separator during the design. The equipment, which had the potential to receive high-pressure substances, should have been designed to be isolated from the hazards and should have proper pressure relief systems, such as rupture discs. Also, for the non-routine operations, such as start-up or purging, there were no written operating procedures or training for the workers. A simple hazard/what-if analysis could have identified the vulnerability of the designed process. With minimum safety considerations, this type of catastrophe could have been avoided.

\section{PROCESS SAFETY IN DESIGN AND PLANT LIFE CYCLE}

The early portion of the project/plant life cycle system is essentially the idea generation phase where different process routes are pondered, economic viabilities are considered, regulatory issues and environmental and safety aspects are assessed. Before materialization of these concepts and start of plant construction, the project goes through an exhaustive design life cycle process which governs the ultimate performance of the project in terms of safety, reliability, yield and profitability. Therefore, the design phases are the most critical phases of a project/plant life cycle system. Plant design starts at project conceptual phase and follows a series of stages including prefront end engineering and design (Pre-FEED), basic engineering or front end engineering and design (FEED), and finally detailed engineering and design.

The concepts of hazards and risks comes into consideration while generating ideas. It is the engineering design phases where process safety plays a crucial role. Different phases of project and plant life cycle are discussed in Figure 5 along with necessary functional process safety elements. It should be noted that, different organization may define and characterize the design steps differently based on projects and practices. But the tasks and sequences remain almost similar as presented in the flow chart. 
Life Cycle/Typical Project Stages

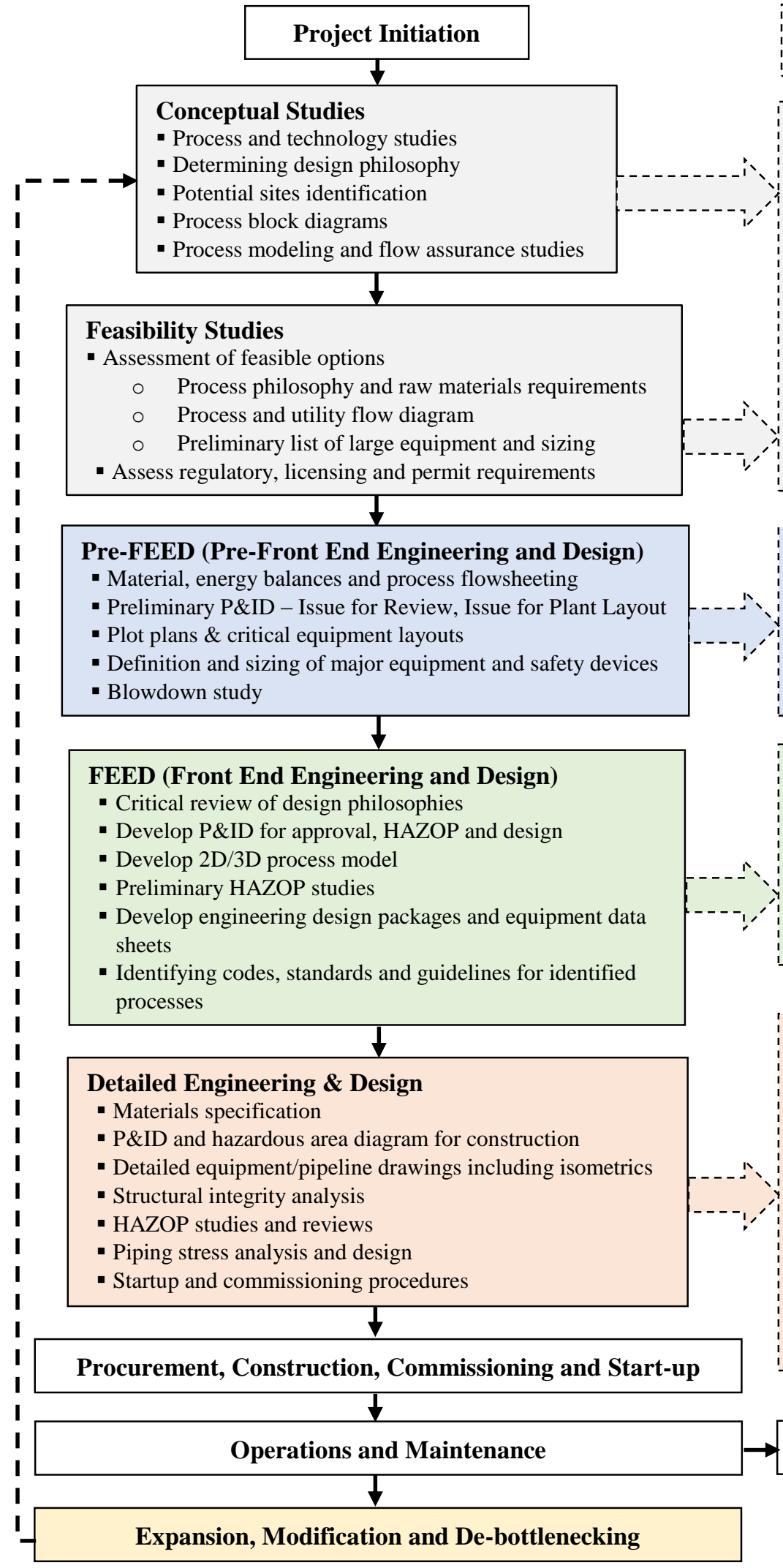

Process Safety Considerations

Process safety overview: Definitions, business case of process safety

- Management system overview; company system \& standards

- Regulatory requirements

- Inherently safer design concepts

- Zoning and land use planning

- Chemical properties - reactivity, toxicity, flammability etc.

- OSHA Recognized And Generally Accepted Good Engineering Practices (RAGAGEP) and BSEE Best Available and Safest Technologies (BAST) considerations

- High value learning incidents

- Life Cycle Analysis (LCA)

- Process Safety Information (PSI) management

- Hazard Identification (HAZID)/ What-if analysis

- Making ALARP decisions

- Barrier management

- Facility siting

- Relief sizing

- Hazard and Operability studies (HAZOP)

- Risk Assessment - Layer of Protection Analysis

- Consequence analysis \& dispersion modeling

- Fire, explosions and runaway reactions-types, causes and prevention

- Safety Critical Equipment (SCE)/ Bypass management

- Mechanical and structural integrity

- Management of Change; As-Built vs. As-Design MOC

- Hazardous area classification and zoning

- Human factors in design

- Alarm Management

- Safety Instrumented System (SIS)/ Safety Integrity Level (SIL) verification

- Consideration of SIMOPS and concurrent activities

- Designing operating manual and procedure

- Assessment and verification

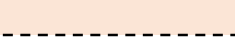

\section{Decommissioning}

Figure 5. Process safety functional elements through a plant design life cycle 
At the very beginning, the business case for process safety should be identified and established. The Center for Chemical Process Safety (CCPS) have identified four benefits of integrating process safety into the business; corporate responsibility, business flexibility, risk reduction and sustained value [11]. These four are some of the essential elements for a healthy business practice and a robust process safety program helps to achieve these qualities. The next item, inherently safer design concepts, is one of the most crucial elements and should be considered throughout the design phases. It is very important to incorporate inherently safer considerations at an early stage of design as it becomes more and more challenging to make changes in later stages; but not too early as a minimum level of process knowledge is required to analyze safer options. Recognized and Generally Accepted Good Engineering Practices (RAGAGEP) and Best Available and Safest Technologies (BAST) are tools for identifying and selecting the best practices for the processes in consideration. Learnings from past incidents should also be considered during this early phase of design.

At the Pre-FEED phase, when preliminary P\&IDs are being prepared with plot plans, one of the key elements to be considered is the issue of facility siting. Kidam et al. (2012) [12] analyzed 284 major incidents caused by poor plant layout (17\% of root causes). Improper plant layout and close proximity of high-occupancy structures are among some of the key findings of Phillips Pasadena disaster (1989) which caused 23 fatalities and 314 injuries [13]. A Hazard identification (HAZID) needs to be conducted at this phase of engineering design to identify health, safety and environmental aspects for further attention. Since the process is finalized and major equipment are defined with safety features, consideration of As Low As Reasonably Practicable (ALARP) concepts in decision making should be understood and practiced. With all these ongoing activities it is necessary to develop and maintain a program for managing all the information systematically for future use. A comprehensive process safety information (PSI) management system is required to record and control all relevant information including chemical properties, process technologies, design data, calculations, drawings, and applied codes and standards.

Next, the engineering design process moves to the basic engineering or FEED phase where preliminary Hazard and Operability (HAZOP) studies are conducted to identify and assess major hazards from different process upsets. Upon completion of HAZOP studies, a Layer of Protection Analysis (LOPA) needs to be conducted for better understanding of risk scenarios. Parallel to this, it is also necessary to perform consequence analysis to ensure incorporation of required safety features to prevent and minimize impacts. Flammability and explosion characteristics of the materials and process should also be analyzed carefully and proper fire walls or blast walls need to be included in plant layout. Absence of blast walls is considered to be the one of the major factors that contributed towards the catastrophic Piper Alpha (1988) incident [14]. Similar to that, the severity of many other incidents could have been minimized by carefully examining explosion or blast overpressure conditions and designing for safety.

High level process safety topics start to kick in with progression of design phase from basic to detailed engineering. Mechanical and structural integrity analysis, hazardous area classification, alarm management, safety integrity level (SIL) verification are among some of the key process safety functional elements that require attention during detailed engineering stage. The provision for safe egress from plant structures, operational and maintenance accessibilities, consideration of future concurrent activities or simultaneous operations (SIMOPS) need to be addressed while finalizing the equipment layout and skid design. Another critical item in the list is human factors 
consideration in design. This factor should be considered throughout the design process, but in the detailed engineering phase maximum attention needs to be put to achieve human-centered design philosophies. Human error was predominant in many major incidents including the explosion at the Formosa Plastics manufacturing plant (2004), where an inadequately designed safety interlock system [7] allowed release of a highly flammable chemical which caused massive explosion and fire.

Finally at the end of the design phase, P\&IDs are issued for construction after completion of detailed HAZOP studies and incorporation of HAZOP action items. This is where the Management of Change (MOC) process kicks in. Prior to this point all the design changes were managed through engineers' document control procedures with different revision versions to allow flexibility in design process. Changes in design procedure is not as rigorous as MOC and therefore special attention needs to be made to ensure all the changes are justified and the changes do not impact the safety and integrity of the total system.

The subsequent phases of a plant life cycle are procurement, construction, commissioning and start-ups where the key elements that govern process safety performances include but not limited to - operating procedures, work permit system, job hazard analysis, emergency management, bypass/overrides management, incident investigation, and audit and verification process. Nonroutine operations is another challenging item to be sensibly managed and understood during maintenance or revamping activities since majority of the catastrophic incidents occurred during these periods. And, for brownfield activities such as expansion or modification of existing plants, all above activities are generally applicable to engineering and design phases.

\section{ROLES OF CONTRACTORS IN DIFFERENT PROJECT ACTIVITIES}

Even though the paper emphasizes the impact of contractors in process safety, it is not only the contractors who govern safety performances and practices. Rather it is a shared responsibility of the owners and the contractors to take a harmonized approach to ensure safe and reliable performance of facilities and process plants. OSHA PSM [15] standards and Safety and Environmental Management Systems (SEMS) [16] discuss the responsibilities of the owners and the contractors which are generally applicable to the contractors working on construction, maintenance or similar activities. Some typical responsibilities of the owners include ensuring contractor training and knowledge in process safety, sharing necessary process safety information and enforcing safety rules and standards in related activities. Contractors need to ensure that they follow the safety rules set in the contracts, build process safety competency among their workforce and work in accordance with owners for safe completion of project jobs. Generally these roles and responsibilities are managed by the owners through a Contractor Health, Safety and Environmental Management program. Each company has its own contractor management policy and programs with detailed information on contractor engagement and management process.

The roles of the design contractors are totally different from the maintenance and the construction teams and it is very important yet challenging to establish specific responsibilities of different parties to integrate process safety in design practices. A brief discussion is presented in this section regarding the roles and responsibilities of the owners and the contractors and how should they 
effectively interact. Rather than individual responsibilities, the owners and the contractors should be partnered in achieving safety goals and high class performances. So the roles of the contractors are discussed here in conjunction with the roles of the owners and their interfaces.

a. The owners should clearly identify and define process safety requirements and their business values; the requirements should be mutually agreed upon the contracts and the contractors should understand their roles and responsibilities to establish the requirements.

b. The owners and the contractors should work together to create a guideline on integrating process safety during engineering design phases. To achieve this, design engineers should have a sound understanding of the different aspects of process safety discussed in the earlier section. A competency matrix similar to Table 2 can be developed to identify essential functional process safety elements specific to design phases. Engineers and technical personnel from both the owner and the contractor companies can go through certain learning programs to have a common baseline of process safety knowledge.

c. The owners and the contractors should have a harmonized approach to determine best practices and process safety standards. The contractors should be responsible for the choices they make during designing a process and the owners need to make sure all the safety expectations are fulfilled prior to start of construction and start-up. In the case of near-capsizing of Thunderhorse production-drilling-quarters (2005), three non-return valves of ballast tank system were mounted in a wrong position which in combination with some malfunctions caused uncontrolled flow of water among ballast tanks [17]. Later the problems were fixed without further damage but this incident clearly shows the importance of having an interactive approach between the owners and the contractors throughout the project life cycle.

d. Focus should be made on effective transfer of the process safety information and design documents. A clear, well-defined communication protocol needs to be established for effective flow of information. The contractors should have a systematic document control process in place and all the control documents need to be transferred to owner's document management system. The contractors should assess the impact of any changes they make during design; especially after finalizing design philosophies and process technologies. All the changes should be justified with clear rationale and documented for future reference.

Thus from an owner's perspective, it is necessary to focus on building awareness and competency in process safety for their partners in projects. And the contractors should cooperate to establish an industry-wide understanding on process safety fundamentals so that different stakeholders can have healthy interactions to achieve common goals. In the next section some existing practices for building process safety competency along with improvement opportunities are discussed. 
Table 2: Process Safety Competency Matrix (' $x$ ' denotes competency requirement)

\begin{tabular}{|c|c|c|c|c|c|c|c|c|c|c|}
\hline & 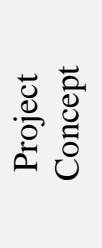 & 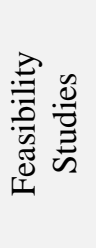 & 䎡 & 至 & 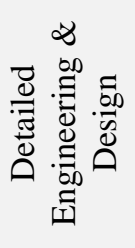 &  &  & 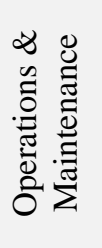 &  & 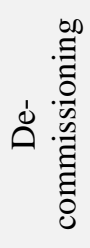 \\
\hline $\begin{array}{l}\text { Process Safety } \\
\text { Overview }\end{array}$ & $\mathbf{x}$ & $\mathbf{x}$ & $\mathbf{x}$ & $\mathbf{x}$ & $\mathbf{x}$ & $\mathbf{x}$ & $\mathbf{x}$ & $\mathbf{x}$ & $\mathbf{x}$ & $\mathbf{x}$ \\
\hline Design for Safety & $\mathbf{x}$ & $\mathbf{x}$ & $\mathbf{x}$ & $\mathbf{x}$ & $\mathbf{x}$ & & & & $\mathbf{x}$ & \\
\hline $\begin{array}{l}\text { Hazard } \\
\text { Analysis/HAZOP }\end{array}$ & & & $\mathbf{x}$ & $\mathbf{x}$ & $\mathbf{x}$ & & $\mathbf{x}$ & & $\mathbf{x}$ & \\
\hline $\begin{array}{l}\text { Risk Assessment and } \\
\text { ALARP }\end{array}$ & & $\mathbf{x}$ & $\mathbf{x}$ & $\mathbf{x}$ & $\mathbf{x}$ & & & & $\mathbf{x}$ & \\
\hline $\begin{array}{l}\text { Best Practices for } \\
\text { Contractor Management } \\
\text { \& Process Safety }\end{array}$ & & $\mathbf{x}$ & & & & $\mathbf{x}$ & $\mathbf{x}$ & & $\mathbf{x}$ & $\mathbf{x}$ \\
\hline $\begin{array}{l}\text { High Value Learning } \\
\text { Incidents }\end{array}$ & $\mathbf{x}$ & $\mathbf{x}$ & $\mathbf{x}$ & $\mathbf{x}$ & $\mathbf{x}$ & & & $\mathbf{x}$ & $\mathbf{x}$ & $\mathbf{x}$ \\
\hline $\begin{array}{l}\text { Life Cycle Analysis } \\
\text { (LCA) }\end{array}$ & $\mathbf{x}$ & $\mathbf{x}$ & $\mathbf{x}$ & & & & & & $\mathbf{x}$ & \\
\hline $\begin{array}{l}\text { Human Factors in } \\
\text { Design }\end{array}$ & & & & & $\mathbf{x}$ & & & & $\mathbf{x}$ & \\
\hline $\begin{array}{l}\text { Facility Siting \& Land } \\
\text { Use Planning }\end{array}$ & & $\mathbf{x}$ & $\mathbf{x}$ & $\mathbf{x}$ & $\mathbf{x}$ & & & & $\mathbf{x}$ & \\
\hline MOC & & & & & $\mathbf{x}$ & $\mathbf{x}$ & & $\mathbf{x}$ & $\mathbf{x}$ & $\mathbf{x}$ \\
\hline SIMOPS & & & & & $\mathbf{x}$ & & $\mathbf{x}$ & $\mathbf{x}$ & $\mathbf{x}$ & \\
\hline Mechanical Integrity & & & & $\mathbf{x}$ & $\mathbf{x}$ & & & $\mathbf{x}$ & $\mathbf{x}$ & \\
\hline Well Integrity \& Control & & & & $\mathbf{x}$ & $\mathbf{x}$ & & $\mathbf{x}$ & $\mathbf{x}$ & $\mathbf{x}$ & $\mathbf{x}$ \\
\hline $\begin{array}{l}\text { Process Safety } \\
\text { Information } \\
\text { Management }\end{array}$ & & & $\mathbf{x}$ & $\mathbf{x}$ & $\mathbf{x}$ & & $\mathbf{x}$ & $\mathbf{x}$ & $\mathbf{x}$ & $\mathbf{x}$ \\
\hline Incident Investigation & & & & & & $\mathbf{x}$ & $\mathbf{x}$ & $\mathbf{x}$ & $\mathbf{x}$ & $\mathbf{x}$ \\
\hline SIS/SIL & & & & $\mathbf{x}$ & $\mathbf{x}$ & & & $\mathbf{x}$ & $\mathbf{x}$ & \\
\hline $\begin{array}{l}\text { Operating Procedure - } \\
\text { Design \& Discipline }\end{array}$ & & & & & $\mathbf{x}$ & $\mathbf{x}$ & $\mathbf{x}$ & $\mathbf{x}$ & $\mathbf{x}$ & $\mathbf{x}$ \\
\hline Work Permit System & & & & & & $\mathbf{x}$ & $\mathbf{x}$ & $\mathbf{x}$ & $\mathbf{x}$ & $\mathbf{x}$ \\
\hline Alarm Management & & & & & $\mathbf{x}$ & & $\mathbf{x}$ & $\mathbf{x}$ & $\mathbf{x}$ & \\
\hline $\begin{array}{l}\text { Bypass/Override } \\
\text { Management }\end{array}$ & & & & & $\mathbf{x}$ & & $\mathbf{x}$ & $\mathbf{x}$ & $\mathbf{x}$ & \\
\hline ORR/PSSR & & & & & & & $\mathbf{x}$ & & $\mathbf{x}$ & \\
\hline $\begin{array}{l}\text { Assessment and } \\
\text { Verification }\end{array}$ & & & & & $\mathbf{x}$ & $\mathbf{x}$ & $\mathbf{x}$ & $\mathbf{x}$ & $\mathbf{x}$ & $\mathbf{x}$ \\
\hline Non-routine Operations & & & & & & $\mathbf{x}$ & $\mathbf{x}$ & & $\mathbf{x}$ & $\mathbf{x}$ \\
\hline Emergency Management & & & & & $\mathbf{x}$ & $\mathbf{x}$ & $\mathbf{x}$ & $\mathbf{x}$ & $\mathbf{x}$ & $\mathbf{x}$ \\
\hline $\begin{array}{l}\text { Hazardous Waste } \\
\text { Management }\end{array}$ & & & & & & & & $\mathbf{x}$ & $\mathbf{x}$ & $\mathbf{x}$ \\
\hline
\end{tabular}




\section{PROCESS SAFETY COMPETENCY DEVELOPMENT}

\section{Existing Practices and Programs for Contractors}

'Contractors' is one of the fourteen elements of OSHA's Process Safety Management (PSM) Guidelines [15] which explicitly states that the employers who use contractors to perform work such as design, maintenance, repair, turnaround, major renovation, or any specialty work in and around processes that involve highly hazardous chemicals have to establish a screening process so that they hire and use only the contractors who accomplish the desired job tasks without compromising the safety and health of any personnel at a facility. For contractors whose safety performance on the job is not known to the hiring employer, the employer must obtain information on injury and illness rates or experiences and should obtain contractor references. These standards often only state "what to do" not "how to do it" [18]. The screening processes that OSHA has referred to are best in the interest of both the operators and contractor's safety; however, often the process gets complicated as there are no single standards or guidelines that can be used as a reference by either parties. Many operators and contractors have similar opinion as that of Lovell and Hill [19]. They referred to the fact that the organizations have to rely on trust that the contractors are fully competent without having a high level of control over that assurance. Any Competency Management System (CMS) must include a reasonable level of contractor competency assurance; however, not having detailed information on the course content or guidelines makes them difficult to know the level of competency. Despite having contractor management systems by various organizations', the incidents keep happening. Short Contractor Safety Management (CSM) courses are offered by various institutions [20]. In most of the cases the process safety management overview course is offered with few specific topics. However, there is no comprehensive course package that one could take to increase the competency of an employee.

Of many work performed by the contractors, the design work is one of the most crucial works for the operators as the initial design has lifelong impact on plant safety. Considering process safety in design phases prevents expensive retrofitting and rework to correct hazardous conditions in latter phases. Hence, the objective is to provide enough safety knowledge to the design contractors which would help them to decide on how to recognize and anticipate the design hazards and identify ways to eliminate them with well thought out design features. However, there is no particular standard or required competency program available to do so.

\section{Improvement Opportunities in Competency Development}

The literature research and discussion with the operators and the contractors indicated the need for a comprehensive program to properly addresses the existing challenges and provide a roadmap in improving the contractor competency. For example, various industries have their own Process Safety Competency Matrix as that of Institution of Chemical Engineers (IChemE). IChemE Safety Centre (ISC) published a guidance, "Process Safety Competency - a Model 2015" [21]. They provided various organizational roles with specific area and description of their job duties. Then to establish a competency framework they determined the topics of competency. Twenty-one topics were defined as requiring specific process safety competency based on various guidelines. These topics were then mapped against the six functional elements of safety which are 1) 
knowledge and competence, 2) engineering and design, 3) systems and procedures, 4) assurance, 5) human factors, and 6) culture. Then the competency was defined across 4-tier scale (awareness; basic application; skilled application and proficiency; and mastery or expert) to capture the competency requirement in varied workforce. ISC also indicated how the management of contractors fit in with the six elements of process safety [22]. For each of these elements some specific questions were raised that could help the operators to better evaluate the contractors.

Though there have been some work done to improve contractors' competency in process safety, there is still significant room remains for improvement. There is a certain need for a dedicated process safety program for the EPC design contractors to provide them with a baseline of understanding on process safety concepts.

\section{Current Initiatives}

The project of developing contractors' competency in process safety was initiated by Shell partnering with Mary Kay O’Connor Process Safety Center (MKOPSC) at Texas A\&M University. Soon after Chevron and other major operators, contractors and manufacturing companies supported the idea of developing process safety competency programs focusing on the design engineers. Through joint industrial partners, MKOPSC started its outreach program to identify the gaps and potential training topics specific to EPC contractors. Through an interactive session with 14 participating companies, the team agreed on 18 essential process safety topics. The main goal of this program was identified as to ensure a baseline of understanding about process safety across the industry. The scope of the project was determined as designing learning programs for EPC design contractors to build global competency on process safety.

The next step was to group the 18 identified topics into potential learning programs. Six learning programs were finalized along with major contents which are discussed below -

1. Process Safety Overview: Establish a global set of process safety terminologies, develop understanding on major accident hazards and share the business cases of process safety

2. Design for Safety: Establish a common understanding of Inherently Safer Design (ISD), RAGAGEP and BAST concepts; design for normal/emergency/non-routine scenarios and develop barrier management concepts

3. Risk Management \& ALARP: Establish hazards and risk perspective in decision making, introduction to risk assessment tools and consequence analysis techniques, provide a common definition of ALARP (As Low As Reasonably Practicable) and discuss risk acceptance practices

4. Best Practices for Contractor Management \& Process Safety: Establish expectations for identifying and mitigating risks collaboratively, sharing high value learning incidents and discuss competency assurance practices

5. Human Factors: Apply human factors thought processes to design decisions, discuss the concept of human-centered design and provide an overview of common behavioral traps (confirmation bias, normalization of deviation) 
6. Common Issues/Core Practices to Support Process Safety: Develop understanding on high level process safety topics, for example, management of change (MOC), facility siting, simultaneous operations (SIMOPS), safety critical equipment (SCE), process safety information (PSI) management and others

Now the existing materials are being modified for EPC-design application, with the objective to review with a much larger group. The comments and feedback received will then be incorporated to design a sample program that would contain appropriate content and delivery methods. Similar steps will be taken for the remaining learning modules.

\section{CONCLUSION}

The criticality and significance of contractors' roles throughout the process life cycle are discussed in this article. It is also demonstrated that the design life cycle process governs the ultimate performance of the process plant in terms of safety and reliability in the future. Significant number of incidents have indicated the critical need for programs that covers the entire life cycle of the projects and which will be adopted by the operators/owners and the contractors. However, existing programs are not comprehensive enough to meet the needs of the both parties. Hence, it is important to establish an extensive learning program accepted and driven by both the owners and the contractors. Current initiative is the first step towards achieving the goal of global competency in process safety for a better and reliable engineering design process.

\section{ACKNOWLEDGEMENT}

The authors would like to express their gratitude to Ms. Natalie Salter of Shell and Ms. Ellen Ross of Chevron for providing valuable insights and expertise throughout the project that greatly assisted this work. The authors would also like to thank Mr. Laurence Pearlman, Dr. Ray Mentzer and all other project participants for their valuable insights and contributions.

\section{REFERENCES}

1. Occupational Safety and Health Administration, Commonly Used Statistics, retrieved from https://www.osha.gov/oshstats/commonstats.html. Last Accessed: September 12, 2016.

2. Federal Emergency Management Agency, 'Phillips Petroleum Chemical Plant Explosion and Fire', USFA-TR-035/October 1989. Retrieved from https://www.usfa.fema.gov/downloads/pdf/publications/tr-035.pdf Last Accessed: September 12, 2016.

3. Oil \& Gas Journal, 'Arco Spells out Cause of Channelview Blast', January 1991, retrieved from http://www.ogj.com/articles/print/volume-89/issue-2/in-this-issue/gas-processing/arcospells-out-cause-of-channelview-blast.html Last Accessed: September 12, 2016.

4. Occupational Safety and Health Administration, Accident Report Detail, retrieved from https://www.osha.gov/pls/imis/accidentsearch.accident_detail?id=110318540 Last Accessed: September 12, 2016. 
5. U.S. Chemical Safety and Hazard Investigation Board, Investigation Report, Catastrophic Vessel Over-pressurization, March 4. Pitkin, Louisiana: Sonat Exploration Company (No.1998-002-I-LA). 2000.

6. Michael McCann, Explosion and Asphyxiation Deaths among Contract Employees in Industrial Plants, December 2003, retrieved from http://citeseerx.ist.psu.edu/viewdoc/download?doi=10.1.1.570.2902\&rep=rep1\&type=pdf Last Accessed: September 12, 2016.

7. U.S. Chemical Safety and Hazard Investigation Board, Investigation Report, Formosa Plastics Vinyl Chloride Explosion. Illiopolis, IL: Formosa Plastics (No. 2004-10-I-IL). 2007.

8. U.S. Chemical Safety and Hazard Investigation Board, Investigation Report, T2 Laboratories Inc. Reactive Chemical Explosion, December 19. Jacksonville, FL: T2 Laboratories Inc. (No. 2008-3-I-FL). 2009.

9. Bartlit, J. F. H., S. N. Sankar, and S. C. Grimsley. "National Commission on the BP Deepwater Horizon Oil Spill and Offshore Drilling." Macondo-The Gulf Oil Disaster-Chief Counsel's Report, 2011.

10. Carson, Phillip. "Ink dust explosion and flash fires." Loss Prevention Bulletin 247, 2016.

11. Center for Chemical Process Safety, The Business Case for Process Safety, $2^{\text {nd }}$ Edition, 2006.

12. Kidam, Kamarizan, and Markku Hurme. "Design as a contributor to chemical process accidents." Journal of Loss Prevention in the Process Industries 25.4. (2012): 655-666.

13. Bethea, Robert M. "Explosion and fire at the Phillips Company Houston Chemical Complex, Pasadena, TX." Proc. SACHE Faculty Workshop on Designing for Safe and Reliable Process Operations. 2003.

14. Pate-Cornell, M. Elisabeth. "Learning from the piper alpha accident: A postmortem analysis of technical and organizational factors." Risk Analysis 13 (1993): 215-215.

15. Occupational Safety and Health Administration, Process Safety Management, U.S. Department of Labor, OSHA 3132, 2000.

16. Bureau of Safety and Environmental Enforcement, Safety and Environmental Management Systems, 30 CFR Part 250, 2013.

17. Nybø, Roar. Can a modern semi-submersible oil rig sink (without some sort of explosion occurring)? 2015. Retrieved from: https://www.quora.com/Can-a-modern-semi-submersibleoil-rig-sink-without-some-sort-of-explosion-occurring. Last Accessed: September 12, 2016

18. Majid, N. D. A.; Shariff, A. M.; Rusli, R., Process Safety Management (PSM) for Managing Contractors in Process Plant. Journal of Loss Prevention in the Process Industries, 2015, (37), 82-90.

19. Sandra Lovell, P. H., Managing Process Safety Competency. Chemical Industry Digest June 2012, 2012.

20. DUPONT Contractor Safety Management (CSM). Retrieved from: http://www.training.dupont.com/psm/contractor-safety-management Last Accessed: September 12, 2016

21. Institution of Chemical Engineers, Process Safety Competency - A Model 2015, IChemE Safety Centre, 2015.

22. Kerin, T., How Management of Contractors Fits in with the ISC's Six Functional Elements of Process Safety. Loss Prevention Bulletin, 2015. 